\title{
In silico analysis of the impact of non-synonymous Single Nucleotide Polymorphisms (nsSNPs) in the human II-6 gene related to autoimmune diseases
}

\author{
Arthur Felipe Ferreira de Freitas ${ }^{1}$; Nara Suzy Aguiar de Freitas ${ }^{2}$; Martín Alejandro Montes ${ }^{3}$; Maria \\ de Mascena Diniz Maia ${ }^{4 *}$
}

1-4 Department of Biology, Genetics, Federal Rural University of Pernambuco, Recife, Brazil.

E-mail adresses: arthurffreitas16@gmail.com (Arthur Felipe Ferreira de Freitas), nara.safreitas@ufrpe.br (Nara Suzy Freitas Aguiar), martin.montes@ufrpe.br (Martín Alejandro Montes), mascenadiniz@hotmail.com (Maria de Mascena Diniz Maia)

${ }^{*}$ Corresponding author

\section{To cite this article:}

Freitas, A.F.F.; Freitas, N.S.A.; Montes, M.A.; Maia, M.M.D. In silico analysis of the impact of non-synonymous Single Nucleotide Polymorphisms (nsSNPs) in the human Il-6 gene related to autoimmune diseases. International Journal of Sciences. Vol. 3, No. 1, 2022, pp.01-05. ISSN 2763-5392.

Received: 11 24, 2021; Accepted: 11 25, 2021; Published: 01 15, 2022

\begin{abstract}
Non-synonymous single nucleotide polymorphisms (nsSNPs) represent a common genetic variation that alters amino acids encoded in proteins. All nsSNPs can potentially affect the structure or function of expressed proteins and therefore can have an impact on complex diseases. Interleukin 6 is a cytokine that acts on the immune system, with anti-inflammatory or pro-inflammatory actions depending on the cell in which it was produced. Overproduction of this cytokine results in complications in various autoimmune diseases, such as ankylosing spondylitis and rheumatoid arthritis. From genetic sequence research in the Ensembl database and software for protein analysis, it was possible to locate five missenses' mutations (rs1282201857, rs1583431936, rs1257406129, rs756681741 and rs2069849) that affect the expression of the IL6 gene, whose impact leads to the emergence of complex diseases.
\end{abstract}

Keywords: IL-6. Genetic polymorphisms. Autoimmune diseases. Bioinformatics. In silico. nsSNPs.

\section{Introduction}

Autoimmune diseases are those in which the response given to autoantigens, by the immune system, causes tissue damage or dysfunction. These diseases can act in a systemic way or may directly affect specific organs or systems of the body (Mackay and Burnet, 1963 apud NGO ST, et al., 2014). Sand develops in individuals with some genetic predisposition and who are exposed to environmental conditions favorable to the onset of the disease (WANG, L et al., 2015). Advances in scientific studies suggest that autoimmune diseases are induced through the interaction of genetic factors and epigenetic alterations that arise from the influence of the environment (HEWAGAMA; RICHARDSON, 2009). However, there are still not enough genetic tools to predict the risk of these diseases (WANG, L et al., 2015).

IL-6 is a pleiotropic cytokine that is pro-inflammatory because it induces the synthesis of acute phase proteins, besides stimulating the differentiation and clonal expansion of B lymphocytes, contributing to the production of immunoglobulins (Hunter CA, Jones AS, 2015). It is usually produced at low levels; however, it is related to numerous infectious, inflammatory, autoimmune diseases and in some types of cancer when its production is elevated to serum levels (TRIKHA, et al., 2003). Its synthesis is performed by several cell types, including endothelial cells, fibroblasts, monocytes and others (ROSSI, et al., 2015). The use of anti-IL6 therapy is an alternative for reducing inflammation caused by overproduction of this cytokine. Its blockade showed positive results in the therapeutic efficacy of the records of medicines used in Castleman's disease and inflammatory diseases such as rheumatoid arthritis and Crohn's disease (ROSSI; et al., 2015).

Single nucleotide polymorphisms (SNPs) are the main and most frequent forms of variations that occur in the human 
genome. The estimate for it to appear in the genome is between 10 and 11 million, that is, it is common for SNPs to appear, on average, every 275 base pairs (bp) (PONTES; et al., 2017). SNPs are generally biallelic and have an average mutation rate that occurs in a given location of base pairs being significantly low (10-7 to 10-9). Thus, SNPs are mostly used for demographic analyses of the human population. (PONTES; et al., 2017).

The IL 6 coding gene is located on the short arm of human chromosome 7 (7p22). This gene is also known as BSF2, HGF, HSF, IFNB2. The SNPs found in the interleukin 6 gene can directly affect the formation of amino acids which, depending on the mutation, can cause damage to the structure and/or function of the resulting protein. SNPs of this gene play a relevant role in the predisposition and progression to lung diseases, such as asthma, bronchitis, chronic obstructive pulmonary disease (COPD) and lung cancer (FERREIRA, et $a l ., 2015)$. IL-6 polymorphisms are strongly related to the risk of developing Kaposi's sarcoma (KS), which is an inflammatory condition angio-proliferative, due to patients previously infected with the HIV virus. (FOSTER, et al., 2000). Interleukin-6 (IL 6) has been implicated in the pathogenesis of Ankylosing Spondylitis disease (ASD). The IL6 variant (rs1800796) seems to play an important role in the pathogenesis of Rheumatoid Arthritis (SILVA, 2018). Thus, this study aimed to provide information on the effects of amino acid substitutions on the protein structure of the IL6 gene, function and association with diseases.

\section{Methodology}

To perform the in silico analyses of the 21 missenses mutations(nsSNPs), some software was used to assist in the studies of the effects caused by changes in protein.

\section{Obtaining the data}

The Ensembl database was used to locate the interleukin 6 gene and isolate the missenses mutations of interest. On the main page of the site, the search frame was populated with Human and IL6 to locate the interleukin 6 gene in humans. After the location of the gene, several important information about IL6 was obtained, such as gene synonyms, chromosome location and transcripts available in the database. For this study, the transcript IL6-201 (ENST00000258743.10) was selected, which contains $1127 \mathrm{bp}$ in length and 212aa in protein. In the bases screens of the transcription, the item cDNA (complementary DNA) was accessed, being possible to visualize the changes of the gene sequences for and selection of the rs variants of interest for the study.

\section{Analysis and review of the impact missenses mutations}

The Software PolyPhen-2 were used to obtain data on possible damage caused by the protein mutation. We use the WHESS.DB tool for quick access to forecast sets deposited in the PolyPhen-2 database. To perform the research and locate the mutation, the protein code obtained in the UniProtKB
$(\mathrm{P} 05231)+$ the position of the mutation in the protein + the wild amino acid + the altered amino acid was inserted in the field (e.g.: P05231 2 N I). Also, in PolyPhen-2, we observed the following results: HumDiv, a rare allele evaluation model, and scores that can range from 0 to 1 , and the closer to 1 , the mutation is likely to cause harm to the individual.

The PROVEAN software was used as a tool that predicts whether an amino acid or indel substitution has an impact on the biological function of a protein, for this, the list of variants selected for this study was inserted. Thus, it was possible to verify whether the result of the mutation was deleterious (score $\geqslant-2.5$ ) or neutral (score $<-2.5$ ). SIFT predictions were also verified in the same software, in which it was possible to classify mutations as tolerated (score $\geqslant 0.05$ ) or harmful (score $>0.05$ ).

The SNP\&GO and PHD-SNP software's scans were used to predict whether the mutation would present disease or be neutral, taking into account the reliability index (IR), which can range from 0 (unreliable) to 10 (reliable), in both software. To make use of SNP\&GO, simply fill the tables with the UniProt code of the protein, the position of the mutation, the wild residue and substitute. In PHD-SNP, it is necessary to fill with the original sequence of the protein, enter the code UniProt, the position of the mutation and the substitute residue.

The UniProt database was used to obtain the necessary information on the protein sequences of the IL6 gene in humans (UniProtKB P05231), as well as the graphic representation of the three-dimensional structure of this cytokine.

To evaluate the structure of the protein after the missense mutations in the fast sequence, the I-TASSER software was used, which is a tool capable of generating and determining the structure and function of the molecules of a protein using molds for simulation of assembly of the structures available in the RCSB PDB (Protein Data Bank) database. The system uses the TM-align structural alignment program to combine the first I-TASSER model with all structures in the PDB library.

\section{Software's}

\section{ENSEMBL}

It is a genome navigator for vertebrate genomes that supports research in comparative genomics, evolution, sequence variation, and transcription regulation. Ensembl annotates genes, calculates multiple alignments, predicts regulatory function, and collects disease data. Ensembl tools include BLAST, BLAT, BioMart and variant effect predictor (VEP) for all supported species.

\section{UNIPROT}

Universal Protein Resource is a comprehensive resource for protein sequence and annotation data.

\section{POLYPHEN-2}

Polymorphism Phenotyping v2 is a tool that predicts the possible impact of the alteration of an amino acid on the structure and function of a human protein, using simple physical and comparative considerations. 


\section{PROVEAN}

Protein Variation Effect Analyzer is a software tool that predicts whether an amino acid or indel substitution (nucleotide insertion or deletion mutation) has an impact on the biological function of a protein. It is useful for filtering sequence variants to identify non-synonymous or indels variants that are predicted to be functionally important.

\section{SNPs \& GO}

SNPs \& GO is a method for predicting unique amino acid polymorphisms (SNPs) deleterious using functional protein annotation probably involved in the insurgency of diseases in humans.

\section{PHD-SNP}

It is a software that predicts the unique nucleotide polymorphisms in humans.

\section{I-TASSER}

This software develops computational methods to predict the three-dimensional structure of protein molecules from the amino acid sequence and deduce biological functions based on the sequence-structure-function paradigm.

\section{Results and Discussion}

In the Ensembl platform, the presence of 170 SNPs variants was identified in the IL6-201 transcript (ENST00000258743.10) of the interleukin coding gene 6 . For the present work, 21 non-synonymous variants (Table 1) were selected in order to observe the possible damages that these mutations could cause in protein structure and function.

The 21 variants were analyzed using different bioinformatics tools to obtain the results. PolyPhen-2 software was used to verify whether the selected variants of the IL6 gene would be classified as benign, possibly harmful, or likely to cause damage to the body. To verify whether the mutation was neutral or deleterious, the PROVEAN software was used and the SIFT was applied to observe whether the alteration would be harmful or tolerated by the organism. (Table 2)

In POLYPHEN-2, PROVEAN and SIFT software (Table 2), rs200700194, rs1282201857, rs1583431936, rs934459268, rs199990564, rs755968353, rs125847874, rs1257406129, rs756681741 and rs2069849 present scores that indicate possibilities of risk in protein formation, which may result in diseases. However, from the analysis of these results in the SNP\&GO and PHD-SNP, it was possible to associate only five polymorphisms in the gene with significant results for disease, rs1282201857, rs1583431936, rs1257406129, rs756681741 and rs2069849 (Table 3). Due to the high reliability index (IR), it is possible to deduce that amino acid substitutions with different chemical composition and/or sizes have a greater impact on protein function and structure. Recent studies reveal that the $\mathrm{C}$ allele of rs2069849 in interaction with abdominal obesity were directly associated with a higher risk of osteoporosis (Ji YF, et al.,
2019).

Analyses in 3D structures corroborate the results of the algorithms, due to the presence and impact of such mutations in conserved regions, important in the function and structure of the protein.

Figure 1 shows the three-dimensional graphic representation of the position of altered amino acids in the protein. RI represents the Reliability Index.

Table 1. Selection of 21 nsSNPs variants of the human IL6 gene for in silico analysis

\begin{tabular}{|c|c|c|c|c|c|}
\hline dbSNP rs & Consequences & Gene & $\begin{array}{l}\text { Code } \\
\text { UniProt }\end{array}$ & $\begin{array}{c}\text { Position in } \\
\text { protein }\end{array}$ & Amino acic \\
\hline RS200700194 & Missense variant & IL6 & $\begin{array}{c}\text { P05231 } 2 \\
\text { N I }\end{array}$ & 2 & $\mathrm{~N} / \mathrm{I}$ \\
\hline RS1224052258 & Missense variant & IL6 & $\begin{array}{c}\mathrm{P} 052315 \\
\text { S F }\end{array}$ & 5 & $\mathrm{~S} / \mathrm{F}$ \\
\hline RS774003579 & Missense variant & IL6 & $\begin{array}{c}\text { P05231 } 6 \\
\text { T I }\end{array}$ & 6 & $\mathrm{~T} / \mathrm{I}$ \\
\hline RS1212373109 & Missense variant & IL6 & $\begin{array}{c}\text { P05231 } 7 \\
\text { S G }\end{array}$ & 7 & $\mathrm{~S} / \mathrm{G}$ \\
\hline RS1383764310 & Missense variant & IL6 & $\begin{array}{c}\text { P05231 } 9 \\
\text { F S }\end{array}$ & 9 & $F / S$ \\
\hline RS762283178 & Missense variant & IL6 & $\begin{array}{c}\text { P05231 } 10 \\
\text { G A }\end{array}$ & 10 & $\mathrm{G} / \mathrm{A}$ \\
\hline RS767924065 & Missense variant & IL6 & $\begin{array}{c}\text { P05231 } 13 \\
\text { A S }\end{array}$ & 13 & $\mathrm{~A} / \mathrm{S}$ \\
\hline RS760962452 & Missense variant & IL6 & $\begin{array}{c}\text { P05231 } 14 \\
\text { F L }\end{array}$ & 14 & $\mathrm{~F} / \mathrm{L}$ \\
\hline RS1282201857 & Missense variant & IL6 & $\begin{array}{c}\text { P05231 } 17 \\
\text { G V }\end{array}$ & 17 & $\mathrm{G} / \mathrm{V}$ \\
\hline RS1583431936 & Missense variant & IL6 & $\begin{array}{c}\text { P05231 } 21 \\
\text { V G }\end{array}$ & 21 & $\mathrm{~V} / \mathrm{G}$ \\
\hline RS1335707674 & Missense variant & IL6 & $\begin{array}{c}\text { P05231 } 23 \\
\text { P S }\end{array}$ & 23 & $\mathrm{P} / \mathrm{O}$ \\
\hline RS746848366 & Missense variant & IL6 & $\begin{array}{c}\text { P05231 } 24 \\
\text { A P }\end{array}$ & 24 & $\mathrm{~A} / \mathrm{P}$ \\
\hline RS1485376559 & Missense variant & IL6 & $\begin{array}{c}\text { P05231 } 30 \\
\text { V I }\end{array}$ & 30 & $\mathrm{~V} / \mathrm{I}$ \\
\hline RS142759801 & Missense variant & IL6 & $\begin{array}{c}\text { P05231 } 31 \\
\text { P T }\end{array}$ & 31 & $\mathrm{P} / \mathrm{T}$ \\
\hline RS934459268 & Missense variant & IL6 & $\begin{array}{c}\text { P05231 } 83 \\
\text { E G }\end{array}$ & 83 & $\mathrm{I} / \mathrm{O}$ \\
\hline RS199990564 & Missense variant & IL6 & $\begin{array}{c}\text { P05231 } 87 \\
\text { E G }\end{array}$ & 87 & $\mathrm{I} / \mathrm{O}$ \\
\hline RS755968353 & Missense variant & IL6 & $\begin{array}{c}\text { P05231 } 91 \\
\text { NY }\end{array}$ & 91 & $\mathrm{~N} / \mathrm{Y}$ \\
\hline RS1258447874 & Missense variant & IL6 & $\begin{array}{c}\text { P05231 } 95 \\
\text { M T }\end{array}$ & 95 & $\mathrm{M} / \mathrm{T}$ \\
\hline RS1257406129 & Missense variant & IL6 & $\begin{array}{l}\text { P05231 } \\
100 \text { G R }\end{array}$ & 100 & $\mathrm{G} / \mathrm{R}$ \\
\hline RS756681741 & Missense variant & IL6 & P05231 & 112 & $\mathrm{~L} / \mathrm{V}$ \\
\hline
\end{tabular}


4 Freitas, A.F.F.; Freitas, N.S.A.; Montes, M.A.; Maia, M.M.D. In silico analysis of the impact of non-synonymous single nucleotide polymorphisms (nSSNPS) in the human Il-6 gene related to autoimmune diseases...

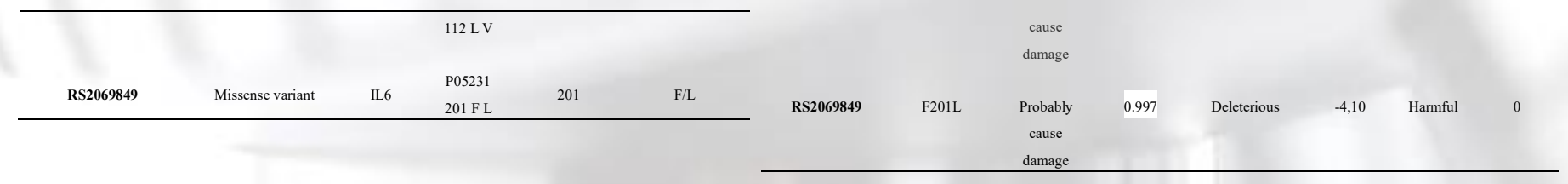

Table 2. Comparison of in silico analysis of 21 snSNPs mutations in the human IL6 gene

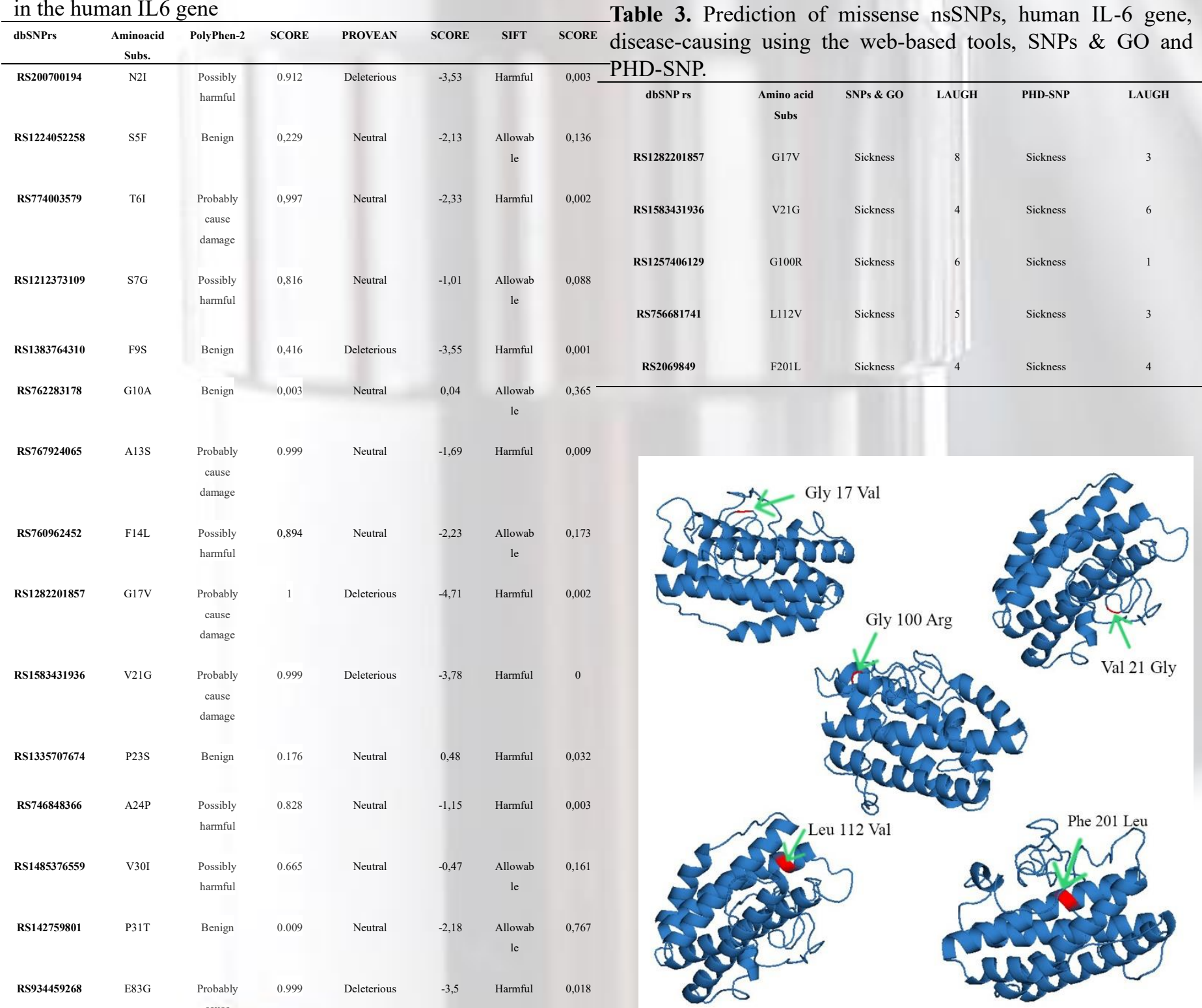

Figure 1. Localization of the position of altered amino acids in the protein due to the missense mutations of the IL6 gene considered in this study that cause diseases.

\section{Conclusions}

We conclude that computational algorithms carefully validated in the context of other evidence can be an important tool for the classification of missense variants. We can also observe that gene polymorphisms may be correlated with various human diseases and can be considered good therapeutic markers. 


\section{Acknowledgments}

To the Federal Rural University of Pernambuco for its support.

\section{References}

[1] NGO, S.T.; STEYN, F.J.; MCCOMBE, P.A. Gender differences in autoimmune disease, Frontiers in Neuroendocrinology, v.35, n.3, p. 347-369, ago. 2014. Disponível em: https://www.sciencedirect.com/science/article/pii/S0091 302214000466?via\%3Dihub. Acesso em: 05 out. 2021.

[2] 5WANG, Lifeng; WANG, Fu?Sheng; GERSHWIN, M. Eric. Human autoimmune diseases: a comprehensive update. Journal of internal medicine, v.278, n.4, p.369395, 2015. Disponível em: https://onlinelibrary.wiley.com/doi/10.1111/joim.12395. Acesso em: 05 out. 2021.

[3] HEWAGAMA, Anura; RICHARDSON, Bruce. The genetics and epigenetics of autoimmune diseases. Jounal of Autoimmunity, v.33, n.1, p.3-11. ago. 2009. Disponível

https://www.sciencedirect.com/science/article/abs/pii/S0 896841109000523?via\%3Dihub. Acesso em: 05 out. 2021.

[4] 6HUNTER, C. A.; JONES, S. A. IL-6 as a keystone cytokine in health and disease. Nature Immunology. v.16, n.5, p. 448-457, 2015. Disponível em: https://www.nature.com/articles/ni.3153\#: :text=IL\%2 D6\%20represents\%20a\%20keystone,location $\% 2 \mathrm{C} \% 201$ ocation $\% 2 \mathrm{C} \% 20$ location'. Acesso em: 20 set. 2021

[5] TRIKHA, Mohit. et al. Targeted Anti-Interleukin-6 Monoclonal Antibody Therapy for Cancer. Clinical cancer research, v.9, n.13, p. 4653-4665, 15 out. 2003. Disponível

em: https://clincancerres.aacrjournals.org/content/9/13/4653. long. Acesso em: 05 out. 2021.

[6] ROSSI, Jean-François. et al. Interleukin-6 as a therapeutic target. Clinical cancer research, v.21, n.6, p. 1248-1257. mar. 2015. Disponível em: https://clincancerres.aacrjournals.org/content/21/6/1248. long. Acesso em: 05 out. 2021.

[7] Pontes, L., Sousa, J., \& Medeiros, R. SNPs and STRs in forensic medicine. A strategy for kinship evaluation. Archives of Forensic Medicine and Criminology, v.67, n.3, p.226-240, mar. 2017. Disponível em: https://www.termedia.pl/SNPs-and-STRs-in-forensicmedicine-A-strategy-for-kinshipevaluation,82,31659,1,1.html. Acesso em: 05 out. 2021.

[8] FERREIRA, Michele Berger. et al. Polimorfismo no gene da interleucina-6 e sua relação com suscetibilidade às doenças pulmonares em crianças e adolescentes. Revista Jovens Pesquisadores, Santa Cruz do Sul, v. 5, n. 1, maio 2015. p.2237-048. Disponível em: $<$ https://online.unisc.br/seer/index.php/jovenspesquisad ores/article/view/5774>. Acesso em: 15 set. 2021.

[9] FOSTER, Charles B., et al. An IL6 promoter polymorphism is associated with a lifetime risk of development of Kaposi sarcoma in men infected with human immunodeficiency vírus. Blood, v.96, n.7, p.2562-2567, out. 2000. Disponível em: https://www.sciencedirect.com/science/article/pii/S0006 497120543693. Acesso em: 05 out. 2021.

[10] SILVA, Marília Lins e. avaliação dos níveis séricos e polimorfismos genéticos de citocinas envolvidas com as respostas th 1 , th 2 e th 17 em indivíduos com artrite reumatoide. ATTENA Repositório Digital da UFRPE, Recife, 2018. Disponível em: https://repositorio.ufpe.br/handle/123456789/32903. Acesso em: 20 set. 2021.

[11] Ji YF, Jiang X, Li W, Ge X. Impact of interleukin-6 gene polymorphisms and its interaction with obesity on osteoporosis risk in Chinese postmenopausal women. Environmental Health and Preventive Medicine. 24, 48, 13 de julho de 2019. Disponível em: https://environhealthprevmed.biomedcentral.com/article s/10.1186/s12199-019-0803-y\#citeas. Acesso em: 20 set. 2021. 